\section{A World in Flux. Introduction}

Steven Faerm *

\begin{abstract}
The present state of the world is in flux. Globally, communities and individuals are experiencing tremendous change, instability, transition, mobility, and uncertainty. Amidst this tenuous future, how are artists, designers, and educators responding? How can we prepare and strengthen our future through pragmatic or theoretical means? What is the role of design, the designer, and design education in such pronounced states of flux? It is with this desire to examine, question, and propose new insights into the current global state of flux that we present our journal. The authors consider the contemporary landscape from diverse perspectives and offer speculations and insights in pedagogy, student development, design education, entrepreneurship, economics, design systems, globalization/localization, sustainability, commercial media, sociology, and design practice/ industry.
\end{abstract}

Keywords: design education - student development - entrepreneurship - design partnerships - internships - sustainability - design systems - globalization - localization - fashion media - diversity - consumerism - luxury

[Abstracts in spanish and portuguese on page 158]

${ }^{*}$ Steven Faerm is an Associate Professor of Fashion Design at Parsons School of Design (Program Director, BFA Fashion Design, 2007-2011). A Parsons alumnus (94') and Designer of the Year Nominee, he began teaching in 1998 while working for designers Marc Jacobs, Donna Karan, Kenneth Richard, and more. He has been recognized for his teaching by winning "The University Distinguished Teaching Award" and The School's "Teaching Excellence Award.”

Steven has created college- and pre-college programs and courses for Parsons and other leading international institutions, and has served on academic review boards for Rhode Island School of Design, Pratt Institute, Virginia Commonwealth Institute (VCU), Otis College of Art and Design, and Marist College. He has taught and lectured for institutions including Harvard University, Massachusetts Institute of Technology (MIT), Brown University, Donghua University in Shanghai, The University of Palermo (UP) in Buenos Aires, and The Spero Villioti School in South Africa. Since 2012, he has co-produced an academic journal dedicated to design education between Parsons and UP.

His publications include two books that are featured on international college-level required reading lists and available in seven languages: Fashion Design Course: Principles Practices, and Techniques and Creating a Successful Fashion Collection: Everything You Need 
to Develop a Great Line and Portfolio. He is currently writing a third book about design education and pedagogy while publishing ongoing research studies in academic journals and serving as a consultant for five publishing houses.

Areas of scholarship and research included the future of art and design education, pedagogy, and student development.

\section{Flux [fluhks] (noun)}

1. continuous change, instability, transition, mobility, passage, or movement.

We are in flux. Around the world, communities are experiencing tremendous change, transition, and instability that permeate daily life. It seems everyone shares the same growing concerns given the global scale and subsequent impact of our diverse dilemmas: Donald Trump's presidency; rising terrorism; Brexit and the European Union; conflict in the Middle East; immigration, diaspora, and rising nationalism; the growing economic divide; affordable healthcare; racial and religious tensions; environmental depletion and global warming; and many more. Our contemporary lives are one of ceaseless uncertainty, worry, and anxiety; our thoughts remain fixated on the 'what-ifs' of the globally intertwined political, social, environmental, and economic futures.

Amidst this dense 'fog' of an uncertain and tenuous future, how are artists, designers, and educators reacting and responding? How can we successfully prepare in both short- and long-term situations? How are moments of flux recorded by and reflected in the histories of art and design? Can we learn from the past to prepare and strengthen our future? In the growing tumult, what is the role of design, the designer, and design education? How can practitioners, industries, and/or design educators improve the status quo via pragmatic or theoretical means? As the philosopher Hegel famously noted, "the owl of Minerva spreads its wings only with the falling of the dusk" -we understand a historical condition just as it passes away. How will future scholars and practitioners reflect upon our current period of flux and how we, as design practitioners and design educators, navigated the volatile landscape?

Despite its unstable character, a period of flux can benefit and improve society; history suggests sudden sparks of societal upheaval can elicit profound creativity and progress. Through emotional and even physical hardships, individuals and communities imagine a better world and a better way -no matter how fantastical or mundane- to "escape" their present circumstances. A desperation can take hold from which the creative soul needs to express itself no matter the resources, the outcome, or the application. After all, in dire circumstances, what is there to lose? Throughout history, these creative movements ranged in scope and impact, and encompassed the visual, the textual, and the auditory. The Hippies, Abstract Expressionism, The Beats, The Lost Generation literary movement, Art Deco, The Dadaists, Guerilla Girls, Bauhaus, Die Brücke, Punk music, Russian Futurism, Scuola Metafisica, Experimental Music, and many other artistic movements were all spawned during or shortly after pronounced societal change. The very nature of flux "stirs the pot" and unsettles a dormant, complacent mind. 
It is with this desire to examine, question, and propose new insights into the current global state of flux that we present our journal. The authors were asked to consider the contemporary landscape(s) -including the political, social, economic, environmental, and/or cultural- for their papers. In addition, they were asked to consider how designers and/or design educators can negotiate and/or prepare for such states of pronounced flux via pragmatic or theoretical means. Collectively, the authors' papers address a wide assortment of topics including pedagogy, student development, design education, entrepreneurship, economics, design systems, globalization/localization, sustainability, commercial media, sociology, and design practice/industry.

\section{The Articles}

Steven Faerm in The School of Fashion ( $\mathrm{SoF}$ ) presents a paper that examines stress, anxiety, pedagogy, and college student development. Faerm contextualizes his essay by first discussing the wider context of the U.S. in flux. Across the country, Americans are experiencing great change and unprecedented stress levels due to factors that include political discord, widening economic disparities, increasing gun violence and other forms of terrorism, tensions between world powers, and more. These events are sensationalized and emotionalized as a ceaseless stream of negative news that, in turn, exacerbates viewers' stress and anxiety. Additionally, the extreme use of digital technology -particularly electronic messaging that never allows the user to "unplug"- further weakens emotional and physical health. These and a host of other stressors contribute to the record numbers of undergraduates seeking services for mental health issues. In response, college campuses are seeking ways to improve students' well-being. One method of support dubbed "Contemplative Pedagogy" is gaining widespread attention in higher education. These simple yet highly effective teaching methods aim to decrease stress levels, improve a sense of well-being, and increase "mindfulness" so that students feel more present in the classroom and beyond. Following the contextual overview of the nation, the campus environment, and select factors that are elevating stress levels, Faerm presents four pedagogical methods that can benefit all levels and types of students. By adopting these methods in and out of the classroom, students' emotional and cognitive development are strengthened, thus promoting long-term academic and personal success.

Thomas Werner in The School of Arts, Media, and Technology (AMT) explores the journal's theme of flux by considering how a community's ideals -namely the fashion industry's- are evolving. Werner posits, "Historically, fashion design -and the imagery that defines it- has shown us where our boundaries lie and how we alternately seek to embrace or break them. This applies not only to the garments we wear, but also to the manner in which fashion addresses the social and cultural norms of the era or country in which they are designed, presented, and advertised." Werner notes the design, presentation, and advertising of fashion has been largely homogeneous and centered around specific (often Westernized) "ideals" of body and ethnicity. However, these ideals featured in runway shows, magazine editorials, and advertisements are becoming increasingly questioned and challenged. In his paper, Werner examines this growing conversation from its nascent, his- 
torical beginnings up to select contemporary representations shown across fashion media platforms. By incorporating qualitative and quantitative data, Werner provides readers an overview of the fashion landscape and evidences the lack of varied representation -namely in ethnic representation and body diversity. Although the fashion industry's progress in this topic is slow, Werner concludes by noting there has been an increase of diverse representation in fashion media and, "In the rapidly changing commercial environment, outdated business practices must evolve to reflect the broader community."

Marie Geneviève Cyr in The School of Fashion (SoF) examines the sudden, rapid growth of China's economy -specifically, that of the apparel industry- and how the resultant hyper-consumerism that followed fostered a shifting identity among many Chinese fashion consumers. Cyr postulates that China's rapid economic boom produced "mass-confusion, enthusiasm, rebellion, romanticism, and idealism. The 1990s manufacturing industries continued to dominate the acceleration of consumerism in the $21^{\text {st }}$ century..." The country's accelerated economy and consumerism led many of the nation's emerging elite to seek vast quantities of luxury goods. The spikes in manufacturing and hyper-consumption "gave China the ultimate opportunity to create a new identity for itself while importing the 'dream' of luxury. By transferring Westernized ideas of consumption into visual symbols, production systems, and communication tools, China channeled an idealized fantasy world." While Westernized symbols and goods have been adopted, newer forms that suit local cultural contexts and aesthetics have emerged. Cyr examines the rise of consumerism, quest for individuality, social impact of giant retail spaces, luxury, authenticity, and spirituality to contribute to the study of fashion and globalization. Cyr's paper also echoes the increasing questions around the economic, social, and cultural logics related to consumption and communication of the constructed significances of fashion.

Noël Palomo-Lovinski, Associate Professor at Kent State University, and Steven Faerm in The School of Fashion (SoF) at Parsons challenge contemporary fashion practices by proposing a new system that aims to better support local communities and sustainability. Increasingly, the fashion industry is re-examining its inefficient and environmentally harmful practices. These practices are due in part to consumers' unyielding needs for instant access, constant change, and low prices -all of which increase a corporation's profits. Yet a paradox exists: How can the fashion industry decrease accelerated and destructive practices while remaining profitable? This binary relationship elicits key questions that aim for a better future. What are the possibilities of domestic apparel manufacturing that utilizes innovative production methods, communication technology, and service systems that, in turn, encourage holistic sustainable practices? What are the possibilities and needs of designers who want to take full advantage of this evolving relationship? Thus, the authors propose a Sustainable Product Service System (SPSS). Across the U.S., local hubs would create a locally considered space that promotes site-specific design, manufacturing, and retail in conjunction with a global perspective, presence, and digital distribution of ideas. The authors liken their proposed system to the local organic food movement that "encourages local organic farming, thoughtful consumption, and methods of creating more closed loop systems (such as composting). These farmers and farmers' markets encourage community participation and transparency. So too can the consumable product of clothing become locally based with greater concern for the environment and the people 
it serves." An enhanced form of design education that can train and support future SPSS entrepreneurs concludes the paper.

Anezka Sebek in The School of Arts, Media and Technology (AMT), and John Jones, Senior Vice President of Design Strategy at Fjord, present the final paper. The globally intertwined phenomena that foster the present state of flux are affecting companies that strive to innovate design, improve systems, and remain lucrative. At the same time, design education aims to provide its students with experiences both inside and outside the institution so they may gain the knowledge required in the hyper-competitive job market. These factors are leading traditional internship models to be reimagined so that students are given the most up-to-date knowledge and methodologies for a fluid and successful transition into the design industries. Sebek and Jones describe a unique internship collaboration between Parsons and the globally esteemed design consultancy Fjord. Select graduate-level students in Parsons' Design and Technology Program engage in a one-week Fjord Immersion Program. They join a Fjord team to explore the firm's design methodologies, contribute their knowledge and skills, and successfully complete a project on-site. This work at Fjord "often sits outside of direct client work and is a perfect vehicle to plug students into an intense, structured process." In their paper, the authors present six case studies of students who successfully enrolled and benefitted from the Immersion Program. A rich description of each project's design methods, project briefs, and outcome(s) are provided so that the reader gains an understanding of the students' cognitive and creative development during the collaborative experience. By participating in such innovative internship programs, students gain tangible, "real world experience" while the design firm gains access to the students' unbridled creativity that may improve and strengthen the firm's existing practices.

\section{Parsons School of Design}

As a leader in art and design education, Parsons School of Design in New York City is considering the future of the art and design education and practice through ongoing conversations and evolving academic philosophies. Parsons contains five Schools: The School of Fashion (SoF); The School of Constructed Environments (SCE); The School of Art, Design, History, and Theory (ADHT); The School of Arts, Media, and Technology (AMT); and The School of Design Strategies (SDS). Within each School, graduate and undergraduate programs house disciplines that relate to one another. For example, in AMT, the programs of Fine Arts and Illustration are contained; SCE offers graduate and undergraduate degrees in Architecture and Interior Design; and SoF offers programs in Fashion Design and Fashion Marketing. While these Schools offer students their own areas of disciplinary study, broader philosophies in art and design education are influencing programs' academic frameworks and curricula in order to contextualize each student's area of study; the importance for this breadth -and depth- has even led to the creation of a graduate-level interdisciplinary program and undergraduate course pathways that allow students to experience multiple Schools and the broader New School University offerings, thus supporting the belief that "design thinking" and cross-disciplinary partnerships may reshape design education and professional practice. 
Resumen: El estado actual del mundo está en movimiento. A nivel mundial, las comunidades y las personas están experimentando cambios tremendos, inestabilidad, transición, movilidad e incertidumbre. En medio de este tenue futuro, ¿cómo responden los artistas, los diseñadores y los educadores? Cómo podemos preparar y fortalecer nuestro futuro a través de medios pragmáticos o teóricos? ¿Cuál es el papel del diseño, el diseñador y la educación del diseño en estados de flujo tan pronunciados? Es con este deseo de examinar, cuestionar y proponer nuevos conocimientos sobre el estado actual de flujo global que presentamos a nuestra revista. Los autores consideran el paisaje contemporáneo desde perspectivas diversas y ofrecen especulaciones y perspectivas en pedagogía, desarrollo estudiantil, educación de diseño, emprendimiento, economía, sistemas de diseño, globalización / localización, sostenibilidad, medios comerciales, sociología y práctica / industria del diseño.

Palabras clave: Educación en diseño - desarrollo estudiantil - emprendimiento - asociaciones de diseño - pasantías - sostenibilidad - sistemas de diseño - globalización - localización - medios de la moda - diversidad - consumismo - lujo.

Resumo: O estado atual do mundo está em movimento. Globalmente, comunidades e pessoas estão experimentando mudanças tremendas, instabilidade, transição, mobilidade e incerteza. Em meio a esse futuro tênue, como artistas, designers e educadores respondem? Como podemos preparar e fortalecer nosso futuro através de meios pragmáticos ou teóricos? Qual é o papel da educação em design, design e design em estados de fluxo tão pronunciados? É com esse desejo que examinamos, questionamos e propomos novos conhecimentos sobre o estado atual do fluxo global que apresentamos ao nosso periódico. Os autores consideram a paisagem contemporânea a partir de perspectivas diversas e oferecem especulações e perspectivas em pedagogia, desenvolvimento de estudantes, educação de design, empreendedorismo, economia, sistemas de design, globalização / localização, sustentabilidade, mídia comercial, sociologia e prática / design.

Palavras chave: Educação em design - desenvolvimento de estudantes - empreendedorismo - associações de design - estágios - sustentabilidade - sistemas de design - globalização - localização - moda - diversidade - consumismo - luxo.

[Las traducciones de los abstracts fueron supervisadas por el autor de cada artículo] 